\title{
EFFECT OF HARVESTING TIME ON GRAIN YIELD AND QUALITY CHARACTERISTICS OF SOME RICE CULTIVARS AT DIFFERENT STORAGE PERIODS
}

\author{
Samah M. Aamer, A. S. Gharieb and Hasnaa, A. Ghazy \\ Rice Research Department, Field Crops Research Institute, Agricultural Research Center, \\ 33717 Sakha - Kafr El-Sheikh, Egypt. mail: hasnaa.rrtc@gmail.com
}

Received: Jun. 24, 2021

Accepted: Jul. 13, 2021

\begin{abstract}
The field experiments were conducted at The Experimental Farm of Sakha Agricultural Research Station, Kafr El-Sheikh, Egypt during 2018 and 2019 seasons to investigate the effect of harvest time on grain yield and its attributes as well as grain quality characteristics of some rice cultivars at different storage periods. The experiments were laid out in a split-plot design, with three replications. The main plots were devoted to harvest time i.e. harvest after 7, 14, and 21-day after irrigation cut-off (DAIC). However, the sub-plots were assigned to rice cultivars (Sakha106, Sakha107 and Sakha 108). The grain quality characteristics were studied at 6,9 and 12-month after harvesting. Delaying the harvest date to 21-DAIC lead to a significant decrease in number of filled and unfilled grains/panicle, panicle weight and grain yield compared with 7- and 14-DAIC. The inverse was true in 1000-grain weight. Sakha 108 was superior to Sakha 106 and Sakha 107 in grain yield and its attributes. The highest grain yield was obtained from Sakha 108 at harvest time of 14-DAIC. Moisture content, hulling, milling and head rice percentages were gradually decreased by increasing storage period from 6 to 9 and 12month. The inverse was found in amylose, elongation percentages and gelatinization temperature (GT). The intermediate harvest time 14-DIAC registered the highest values of all grain quality characteristics. Sakha 108 registered the lowest moisture content and the highest values of other grain quality. Generally, Sakha 108 harvested at 14-DAIC achieved the highest grain yield and quality at the 9-month storage period.
\end{abstract}

Key words: Rice, harvesting times, storage periods, cultivars, quality characters.

\section{INTRODUCTION}

Rice (Oryza sativa L.) is the predominant staple food in diets for more than half of the population worldwide and is pivotal for human nutrition, energy supply, and food security. It supplies adequate energy in the form of calories and is a good source of thiamine, riboflavin, and niacin (Zhu et al., 2010). Rice has been considered one of the most common foods among all cereals for its nutritional quality. It has higher digestibility, biological value, and protein efficiency ratio owing to the presence of a higher percentage of lysine than that of wheat (El-Kady et al., 2013). It is the most important summer cereal crop of traditional rice-growing areas of Egypt and is among the major export commodities. There are important questions concerning the effect of irrigation cut-off and time of harvest on rice grain yield and grain quality that contribute directly to profit. Early harvest may lead to increases in the unfilled and immature grains. These premature grains may result in partially chalky kernels and milk-white kernels and increases the thickness of the bran and aleuronic layers (Hossain et al., 2009). Baktiar et al., (2013) reported that rice harvesting at 30 to 35 days after flowering was found to be suitable for higher grain quality in respect of head rice, elongation (\%) and amylose content. Jewel et al., (2016) concluded that harvesting at 30 to 35 
Samah M. Aamer, et al.,

days after flowering was found to be suitable for all the grain quality characters, for avoiding immature stage as well as shattering loss.

Storage is an essential step in rice processing after harvest to extend shelflife and commercial consumption. Effective grain storage techniques are now indispensable in many countries, and strong demand to develop such techniques has been increasing to meet growing requirements for food, about $70 \%$ extra food production will be desired by the year 2050 while a high level of grain loss can be more than $20 \%$ (Katta et al., 2019). Jungtheerapanich et al., (2017) revealed that the storage efficacy of paddy rice was significantly increased due to increasing storage periods from 2 to 4 and 6 months. El-Dalil (2017) indicated that storing the grains of Giza 179 rice cultivar for 9 months gave the highest values for hulling, milling and broken percentage. Tong et al., (2019) reported that increasing storage period of paddy rice led to a decrease in breakdown grains and an increase in head rice yield. Also, rice grain aging occurring during storage is inevitable and responsible for the changes in rice appearance, milling, eating, cooking, and nutritional quality. Katta et al., (2019) revealed that rice grain quality characters were reduced with increasing storage periods from 6 to 12,18 and 24 months. Marques et al. (2014) showed that milling characteristics in terms of broken percentage and head rice yield showed non-significant differences among the varieties. Hence, this study was established to examine the effect of harvest time at different storage periods on grain yield and its component as well grain quality characters of some rice cultivars.

\section{MATERIALS AND METHODS}

Two field experiments were conducted at The Experimental Farm of Sakha Agricultural Research Station, Kafr El-
Sheikh, Egypt during the 2018 and 2019 seasons. The purpose was to investigate the effect of different harvesting time on grain yield and component as well as grain quality characters of some rice cultivars at different storage periods. All experiments were preceded by barley crop (Hordum spp.). The soil was clay with pH 8.05 and 8.20 and an organic matter content of 1.65 and $1.60 \%$. The total $\mathrm{N}$ was 520 and $500 \mathrm{ppm}$ in both seasons, respectively. The experiments were laid out in a split-plot design, with three replications. The main plots were devoted to three harvesting times namely harvest after 7, 14 and 21 days after irrigation cut-off (DAIC). Irrigation cut-off was done after 20 days of heading. The sub-plots were assigned to three rice cultivars: Sakha 106, Sakha107, and Sakha108. The sub plot size was $16 \mathrm{~m}^{2}$ $(4 \times 4 \mathrm{~m})$. The experimental sites and the nursery were well ploughed and leveled. The experimental sites and the nursery were well ploughed and leveled. Nitrogen, phosphorus, and zinc $\left.(\mathrm{Zn} \mathrm{SO})_{4}\right)$ as well as all other cultural practices were applied as recommended. Seeds of rice cultivars, at the rate of $120 \mathrm{~kg} / \mathrm{ha}$ each, were soaked in sufficient water for 24 hours and incubated for another 48 hours to enhance each germination. The experiments were sown on the $2^{\text {nd }}$ and $5^{\text {th }}$ of May in the two seasons of study, respectively. Seedlings were carefully pulled from the nursery after 30 days from sowing and distributed through the plots. Seedlings were manually transplanted in $20 \times 20 \mathrm{~cm}$ spacing between hills and rows, at the rate of 2-3 seedlings/hill. The other usual agricultural practices of growing rice were performed as the recommendation of Rice Research and Training Center .

At harvest, the number of panicles of ten random hills was counted and then, conformed to the number of panicles/hill. Ten panicles were collected randomly 
from each sub plot to estimate number of filled grain and unfilled grain per panicle and 1000-grain weight. The central area of $4 \mathrm{~m}^{2}(2 \times 2 \mathrm{~m})$ of each sub plot was harvested to obtained grain yield. The moisture content of grain yield was adjusted to $14 \%$ and then the yield of the $4 \mathrm{~m}^{2}$ was computed and transferred to tons per hectare.

About $3 \mathrm{~kg}$ of paddy rice grains were taken from each sub plot and dried in open air until moisture content reached $14 \%$, then samples were stored in a wellventilated store in gunny package for 6 , 9 , and 12 months after harvest time during 2018/19 and 2019/20 seasons. At each storage period, moisture content and milling recovery (hulling, milling and head rice percentage) was measured, according to the method described by Juliano (1971) and IRRI (1996). Amylose content was determined by auto-analyzer based on the iodine-colorimetric method (Juliano, 1971). Gelatinization temperature (G.T) is the temperature at which the starch in rice begins the process of cooking. At this point the starch granules take in water and lose their crystalline nature, a change that is irreversible. Temperature of gelatinization process was distinguished (Little et al., 1958).

The combined analysis for the three storage periods was done in each experiment in each season. Data collected were statistically analyzed using the analysis of variance technique in field experiments and combined analysis for the three storage periods in each experiment according to Gomez and Gomez (1984). Duncan's Multiple Range Test was used to compare the treatment means (Duncan 1955). All statistical analyses were accomplished using the analysis of variance technique using "COSTAT" statistical software package.

\section{RESULTS AND DISCUSSION}

\section{Grain yield and yield attributes:}

Data in Table 1 show that number of panicle/ hill did not significantly affected by harvest time in both seasons. This is because the number of panicle per hill is mostly complete at the heading date. Delaying the harvest date to 21 days after irrigation cut-off (DAIC) lead to a significant decrease in the number of filled and unfilled grains/panicle and panicle weight compared with 7 and 14 DAIC, which not differ in these respects in the two seasons. Delay in harvesting results in low moisture content in grains which may increase the losses percentage and consequently decreased the total grains/panicle. These results agree with those found by Atapattu et al (2018) and Ilieva et al., (2019). On the other hand, 1000-grain weight was substantially increased by delaying the harvest date to 14 and 21 DAIC than early harvest at 7 DAIC in both seasons. Early harvest date might be affected grain filling by reducing the period of active grain filling resulted in bad panicle characteristics producing low panicle fertility, more immature grain and light 1000-grain weights. Similar findings were reported by Dewedar (2004), Hossain et al. (2009), Afifah, et al., (2015), Atapattu et al (2018), and Yang, et al., (2019).

Data in Table 1 show that harvest time had a significant effect on grain yield (t/ha) in both seasons. Harvest time at 7 and 14 DAIC, being insignificant, resulted in a markedly increase in grain yield compared with the harvest time at 21 DAIC in the two seasons. Harvest time at 14 DAIC achieved the highest grain yield through increasing some yield attributes such as the number of filled grains / panicle, 1000-grain weight and panicle weight. These results are in a quite agreement with those reported by Dewedar (2004), Hossain et al. (2009), Afifah, et al., (2015), Atapattu et al (2018), and Yang, et al., (2019). 


\begin{tabular}{|c|c|c|c|c|c|c|c|c|c|c|c|}
\hline & 몰 & 点 & & 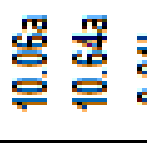 & 号 & $\neq$ & & 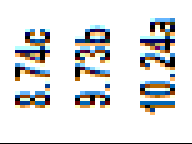 & $\neq$ & $*$ & $\begin{array}{l}5 \\
\text { 罳 }\end{array}$ \\
\hline & 蒠 & 훌 & & 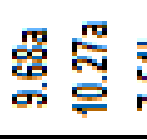 & 몬 & $\neq$ & & 蚂总鸪 & $\nRightarrow$ & $*$ & 蒙 \\
\hline & $\begin{array}{l}\text { 톧 } \\
\text { 듬 } \\
\text { 들 모 }\end{array}$ & 훌 & & 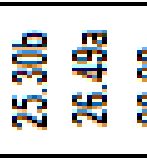 & $\begin{array}{l}\text { 囬 } \\
0\end{array}$ & $\#$ & & 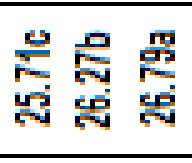 & $\#$ & 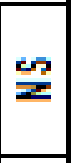 & $\begin{array}{l}\text { 홍 } \\
\text { 홀 }\end{array}$ \\
\hline & 홀 & 吾 & & $\begin{array}{l}\text { 总罗 } \\
\text { 芯㤩 }\end{array}$ & $\begin{array}{l}8 \\
8 \\
8\end{array}$ & $\neq$ & & 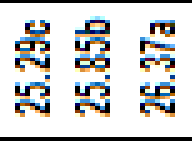 & $\#$ & $m$ & 罢 \\
\hline & 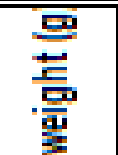 & 물 & & 5 & P & $\neq$ & & 总贵品 & $\neq$ & 을 & 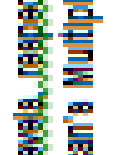 \\
\hline & 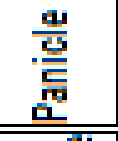 & 훌 & & $\underset{\Rightarrow}{8}$ & 骂 & $*$ & & 量总罢 & $\neq$ & $\approx$ & 를 \\
\hline & 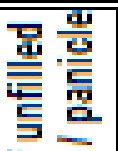 & 물 & & 焉塄 & 㽞 & $\neq$ & & 焉总亭 & 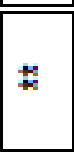 & 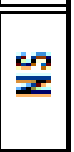 & 语 \\
\hline & 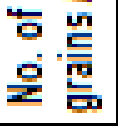 & 울 & & $\begin{array}{l}\mathrm{g} \\
\mathrm{g}\end{array}$ & $\begin{array}{l}\text { 号 } \\
\text { 穷 }\end{array}$ & $\neq$ & & 当量 & $\neq$ & 의 & \\
\hline & 墨 & 물 & & 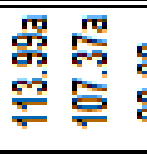 & $\begin{array}{l}8 \\
8\end{array}$ & $\neq$ & & 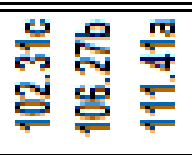 & $\neq$ & 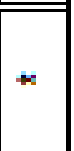 & \\
\hline & 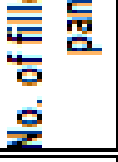 & 훌 & & 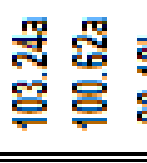 & $\frac{9}{8}$ & $\neq$ & & $\begin{array}{l}\text { 员星罗 } \\
\text { 总 }\end{array}$ & $\neq$ & $\Rightarrow$ & \\
\hline & 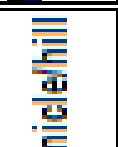 & 물 & & 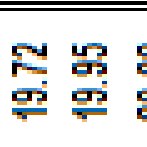 & 렬 & 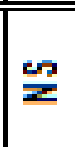 & & 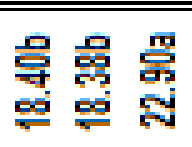 & $\neq$ & 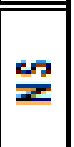 & \\
\hline & $\begin{array}{l}\mathrm{g} \\
\text { 응 } \\
0 \\
\end{array}$ & 훌 & & 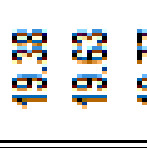 & E & $\underline{z}$ & & ㄹㄹㄹ요용 & $\neq$ & ? & 点 \\
\hline & 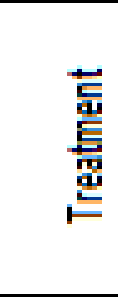 & & 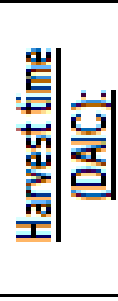 & $\mathrm{m}=$ & $\overline{\mathrm{M}}$ & $\frac{\text { 馬 }}{4}$ & 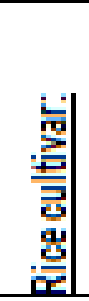 & 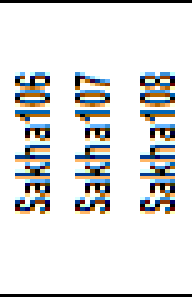 & $\frac{\text { 咅 }}{4}$ & $\begin{array}{l}\text { 들 } \\
\text { 总 } \\
\text { 站 }\end{array}$ & 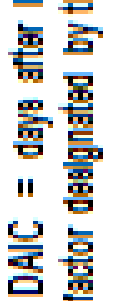 \\
\hline
\end{tabular}


The three rice cultivars significantly varied in all yield attributes in the two seasons (Table 1). The cultivar Sakha 108 was superior to Sakha 107 and Sakha 106 in number of panicle/hill, number of filled /panicle, panicle weight and 1000-grain weight in both seasons. On the contrary, the cultivar Sakha 106 recorded the highest value of unfilled grains number/panicle, while Sakha 108 recorded the lowest one in the two seasons. The superiority of Sakha 108 in panicle weight due to the increase in number of filled/panicle and 1000-grain weight. The results are in accordance with the findings of Metwally et al., (2016) and Howida et al., (2018).

The three-rice cultivars exhibited a significant difference in grain yield in both seasons (Table 1). The cultivar Sakha 108 out-yielded the other two cultivars in grain yield followed by Sakha 107 and Sakha 106. The superiority of Sakha 108 cultivar in grain yield may be due to increase all yield attributes namely number of panicles / hill, number of filled grains / panicle, 1000-grain weight and panicle weight. The results are in accordance with the findings of Metwally et al., (2016).

Results presented in Table 2 showed that the interaction effect between harvest time and rice cultivar on the number of filled grains/ panicle and 1000grain weight was significant in 2019 and
2018 seasons, respectively. At any cultivar, delaying the harvest date decrease number of filled grains / panicle, while, it increased 1000-grain weight. At the same harvest time, the cultivar Sakha 108 recorded the highest values of filled grains number / panicle and 1000-grain weight. The cultivar Sakha 108 produced the greatest number of filled grains / panicle at the early harvest date 7 DAIC and the heaviest 1000-grain weight at the late harvest date 21 DAIC. However, the cultivar Sakha 106 produced the lowest number of filled grains / panicle at the late harvest date 21 DAIC and the lightest 1000 -grain weight at the early harvest date 7 DAIC.

The interaction between harvest time and rice cultivars had a significant effect on grain yield in the two seasons (Table 3). At any cultivar, delaying harvest time to 21 DAIC significantly decreased grain yield compared with the other two harvest times in both seasons. At the same harvest date, Sakha 108 and Sakha 107, being insignificant, surpassed Sakha 106 in grain yield in the two seasons. The highest grain yield was obtained from Sakha 108 at the harvest time 14 DAIC, while the lowest one was obtained from Sakha 106 at the harvest time 21 DAIC. There were no significant difference in grain yield between Sakha 107 and Sakha 108 at the harvest time 14 DAIC in both seasons.

Table 2: Number of filled grains / panicle and 1000-grain weight as affected by the interaction between harvest times and rice cultivars.

\begin{tabular}{|c|c|c|c|c|c|c|}
\hline \multirow{2}{*}{$\begin{array}{l}\text { Harvest } \\
\text { time } \\
\text { (DAIC) }\end{array}$} & \multicolumn{3}{|c|}{$\begin{array}{l}\text { No. of filled grains/ panicle } \\
\text { (2019) }\end{array}$} & \multicolumn{3}{|c|}{$\begin{array}{c}\text { 1000-grain weight }(\mathrm{g}) \\
(2018)\end{array}$} \\
\hline & Sakha106 & $\begin{array}{c}\text { Sakha } \\
107\end{array}$ & $\begin{array}{l}\text { Sakha } \\
108\end{array}$ & Sakha106 & $\begin{array}{c}\text { Sakha } \\
107\end{array}$ & $\begin{array}{c}\text { Sakha } \\
108\end{array}$ \\
\hline 7 & $110.06 \mathrm{bc}$ & $112.52 b$ & $119.41 a$ & $24.37 e$ & $25.04 d$ & $25.47 \mathrm{~cd}$ \\
\hline 14 & $104.70 d$ & $107.38 \mathrm{~cd}$ & $110.02 b c$ & $25.52 \mathrm{~cd}$ & $26.11 b c$ & $26.46 b$ \\
\hline 21 & $92.16 f$ & 98.91e & $104.79 d$ & $25.99 b c$ & $26.39 b$ & $27.19 a$ \\
\hline
\end{tabular}

DAIC = days after irrigation cut-off. Means of each character designated by the same latter are not significantly different at $5 \%$ level using Duncan's Multiple Range Test. 
Samah M. Aamer, et al.,

Table 3: Grain yield ( $t / h a)$ as affected by the interaction between harvest times and rice cultivars.in 2018 and 2019 seasons.

\begin{tabular}{|c||c|c|c||c|c|c|}
\hline \multirow{2}{*}{$\begin{array}{c}\text { Harvest time } \\
\text { (DAIC) }\end{array}$} & \multicolumn{3}{|c||}{2018} & \multicolumn{3}{c|}{2019} \\
\cline { 2 - 7 } & Sakha106 & $\begin{array}{c}\text { Sakha } \\
107\end{array}$ & $\begin{array}{c}\text { Sakha } \\
108\end{array}$ & Sakha106 & $\begin{array}{c}\text { Sakha } \\
107\end{array}$ & $\begin{array}{c}\text { Sakha } \\
108\end{array}$ \\
\hline 7 & $8.79 \mathrm{c}$ & $10.06 \mathrm{ab}$ & $10.74 \mathrm{a}$ & $9.00 \mathrm{~d}$ & $10.28 \mathrm{bc}$ & $10.90 \mathrm{ab}$ \\
14 & $9.62 \mathrm{~b}$ & $10.39 \mathrm{a}$ & $10.81 \mathrm{a}$ & $9.99 \mathrm{c}$ & $10.77 \mathrm{ab}$ & $11.17 \mathrm{a}$ \\
21 & $6.46 \mathrm{e}$ & $7.63 \mathrm{~d}$ & $8.46 \mathrm{c}$ & $7.22 \mathrm{f}$ & $8.16 \mathrm{e}$ & $8.66 \mathrm{de}$ \\
\hline
\end{tabular}

DAIC = days after irrigation cut-off. Means of each factor designated by the same latter are not significantly different at $5 \%$ level using Duncan's Multiple Range Test.

\section{Grain quality characteristics:}

Quality characteristics of rice grains (moisture content, hulling, milling, head rice, amylose, and elongation percentages as well as gelatinization temperature "GT") as affected by harvest time, cultivar and storage period in both seasons are presented in Table 4. Data show that moisture content, hulling, milling, and head rice percentages were gradually decreased by increasing storage period from 6 to 9 and 12 months. The highest values of these technological characteristics of rice grains were produced from storage for 6 months, followed by storage for 9 months and then storage for 12 months in both seasons. In contrary, amylose and elongation percentages and gelatinization temperature (GT) were significantly increased as a result of increasing storage periods of paddy rice grains from 6 to 9 and 12 months. The highest amylose, elongation percentages and gelatinization temperature (GT) were obtained from storage rice grains for 12 months, followed by storage for 9 months and then storage for 6 months in both seasons. These results may be due to biological activity in the grain mass, which includes fungi, bacteria, insects, rodents, and sprouting of grain and continued grain respiration. Also, grain deterioration during storage may be due to the damage in the membrane, enzyme, proteins, and nucleic acid. In addition, accumulations over time such degenerative changes result in complete disorganization of membranes and cell organelles. These findings confirm with those stated by Kanlayakrit and Maweang (2013), El-Dalil (2017), Jungtheerapanich et al. (2017), Katta et al. (2019) Tong et al. (2019).

Data in Table 4 show that harvest time significantly affected all studied quality characteristics of rice grains in both seasons. It could be noticed that the early harvest time 7 DIAC gave the highest moisture content in rice grains (15.25 and $14.39 \%)$, followed by intermediate harvest time 14 DIAC and lastly late harvest time 21 DIAC, which recorded the lowest moisture content in rice grains in both seasons. However, the intermediate harvest time 14 DIAC registered the highest hulling, milling, head rice, amylose, and elongation percentages as well as gelatinization temperature (GT) in the two seasons. Whereas, the second-best values of hulling, milling, head rice, amylose, and elongation percentages, as well as gelatinization temperature (GT) were resulted from the early harvest time 7 days DIAC. The lowest values of hulling, milling, head rice, amylose, and elongation percentages as well as gelatinization temperature (GT) were obtained when harvest time delayed to 21 DIAC in both seasons. The increases in moisture content in rice grains at early 


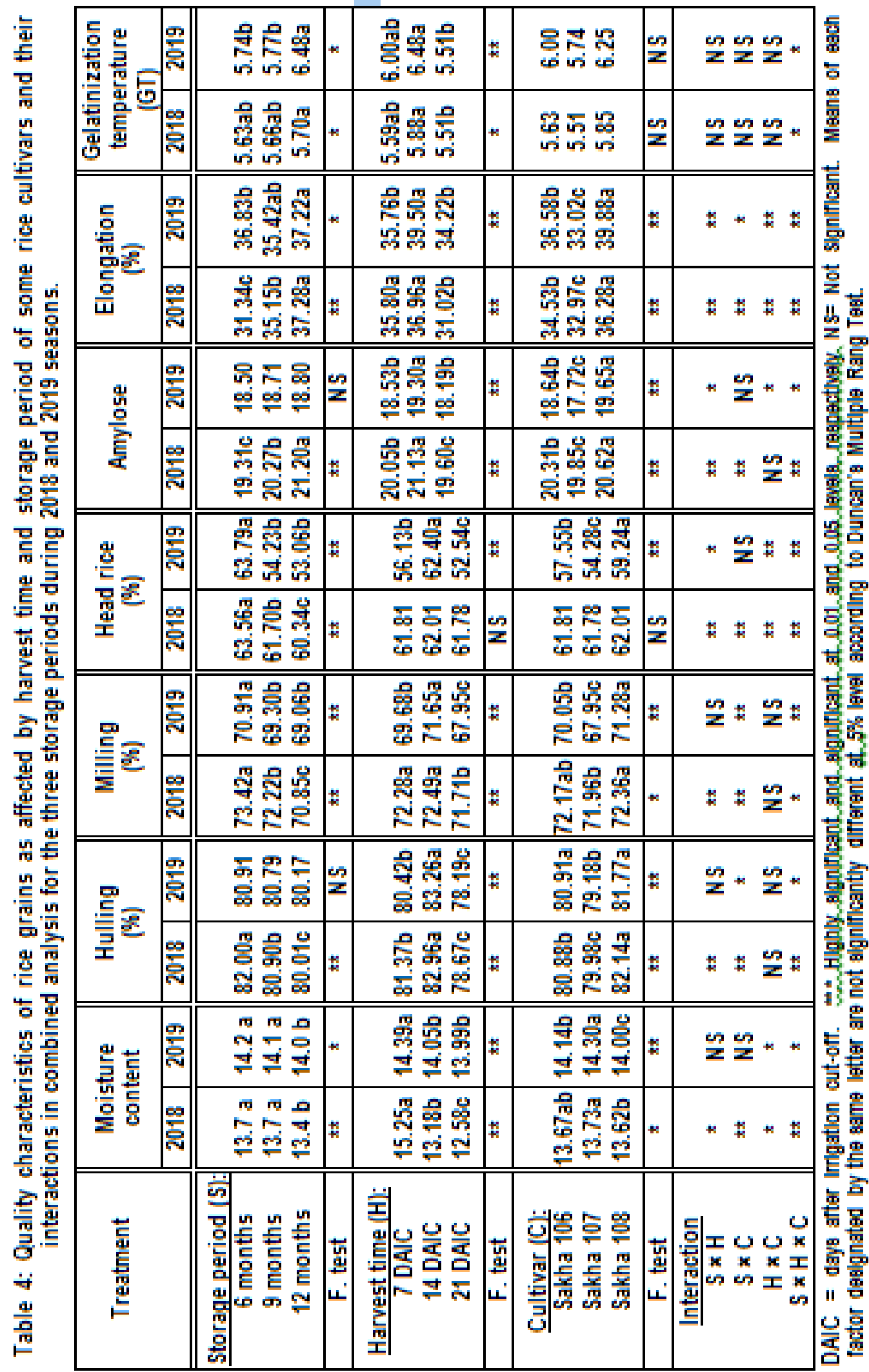


harvest 7 DIAC may be attributed to that rice grains did not reach the appropriate maturity stage, which might increase moisture content and loss of yield with poor quality of grains. However, the increases in quality characters of rice grains by intermediate harvest time 14 DIAC may be ascribed to rice grains reached to suitable grain maturity stage. The right stage for harvest is determined when panicles turn into golden yellow and the grains contain about 20 percent moisture. When the moisture in the paddy grains reaches 16-17 percent in the standing crop in the fields, the crop sustains a heavy loss owing to shattering and damage by birds and rodents. In general, three criteria are taken into consideration to specify the right time of harvesting which are. (i) the moisture content of the grains, (ii) the number of days after planting to flowering, and (iii) the dry matter of the plant or seed. These results are in good accordance with those stated by Hossain et al. (2009), Baktiar et al. (2013), and Jewel et al. (2016).

The obtained results showed that the three studied rice cultivars i.e. Sakha 106, Sakha107, and Sakha108 cultivars significantly differed in quality characters of rice grains (moisture content, hulling, milling, head rice, amylose, and elongation percentages as well as gelatinization temperature "GT") in both seasons as shown in Table 4. It could be observed that Sakha 108 cultivar registered the lowest moisture content percentages and the highest hulling, milling, head rice, amylose and elongation percentages, and gelatinization temperature (GT). Sakha 107 cultivar recorded the highest moisture content percentages and the lowest hulling, milling, head rice, amylose and elongation percentages, and gelatinization temperature (GT) in both seasons. However, Sakha 106 cultivar resulted in the second-best values of moisture content, hulling, milling, head rice, amylose and elongation percentages, and gelatinization temperature (GT) in both seasons. The previously mentioned results might be related to genetic factors which resulted from genetic makeup relations for the studied rice cultivars. The obtained results of this study are partially conformable with reported by Verma et al. (2015), Rather et al. (2016), and Katta et al. (2019).

With regard to the interactions among the studied factors (harvesting and storage periods and rice cultivars), enormous of them were statistically significant in most cases in both seasons as shown in Tables 5 and 6 . The second order interaction of storage period $x$ harvest time $x$ rice cultivars will be discussed. Moisture content, hulling, milling, head rice, amylose and elongation percentages as well as gelatinization temperature (GT) were significantly affected by the second order interaction in both seasons. The highest moisture content percentage in grains were recorded when early harvest time 7 DAIC of Sakha 107 rice cultivar at storage for 6 months. However, the lowest moisture content percentage in grains were recorded when delay harvest time 21 DAIC of Sakha 108 rice cultivar at storage grains for 12 months. While, the highest hulling, milling and head rice percentages of rice grains were recorded when intermediate harvest time 14 DAIC of Sakha 108 rice cultivar and storage grains for 6 months. The lowest hulling, milling and head rice percentages of rice grains were recorded when delay harvest time to 21 DAIC of Sakha 107 rice cultivar at storage grains for 12 months. Whereas, the highest amylose and elongation percentages and gelatinization temperature (GT) of rice grains were recorded when intermediate harvest time 14 DAIC of Sakha 108 rice cultivar at storage grains for $\mathbf{1 2}$ months, 
while, the lowest amylose and elongation percentages and gelatinization temperature (GT) of rice grains were recorded when delay harvest time to 21 DAIC of Sakha 107 rice cultivar at storage grains for 6 months.

Table 5: Moisture content, hulling, milling and head rice percentages as affected by the interaction among harvest time, storage times of some rice cultivars in combined analysis for the three storage periods during 2018 and 2019 seasons.

\begin{tabular}{|c|c|c|c|c|c|c|c|c|c|c|}
\hline \multirow{2}{*}{\multicolumn{3}{|c|}{ Treatment }} & \multicolumn{2}{|c|}{$\begin{array}{c}\begin{array}{c}\text { Moisture content } \\
(\%)\end{array} \\
\end{array}$} & \multicolumn{2}{|c|}{ Hulling (\%) } & \multicolumn{2}{|c|}{ Milling (\%) } & \multicolumn{2}{|c|}{ Head rice (\%) } \\
\hline & & & 2018 & 2019 & 2018 & 2019 & 2018 & 2019 & 2018 & 2019 \\
\hline \multirow{3}{*}{ 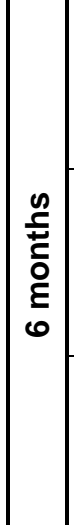 } & 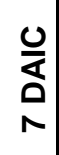 & $\left|\begin{array}{ll}S & 106 \\
S & 107 \\
S & 108\end{array}\right|$ & \begin{tabular}{|c}
$15.36 a b$ \\
$15.46 a$ \\
$15.36 a b$
\end{tabular} & $\begin{array}{c}14.36 a b \\
14.64 a \\
14.36 a b\end{array}$ & $\begin{array}{c}81.88 \mathrm{e}-\mathrm{g} \\
81.33 \mathrm{gh} \\
83.67 \mathrm{~b}\end{array}$ & $\begin{array}{c}80.67 b \\
79.55 b c \\
81.78 a b\end{array}$ & $\begin{array}{l}73.67 a \\
73.67 a \\
73.77 a\end{array}$ & $\begin{array}{l}70.67 \mathrm{~b} \\
69.55 \mathrm{bc} \\
71.78 \mathrm{ab}\end{array}$ & $\begin{array}{l}63.44 a \\
63.33 a \\
64.33 a\end{array}$ & $\begin{array}{l}64.00 a \\
60.78 a \\
65.11 a\end{array}$ \\
\hline & $\begin{array}{l}0 \\
0 \\
\Delta \\
\vdots \\
\sigma\end{array}$ & $\left|\begin{array}{ll}S & 106 \\
S & 107 \\
S & 108\end{array}\right|$ & \begin{tabular}{|c}
$13.30 \mathrm{e}-\mathrm{g}$ \\
$13.46 \mathrm{e}$ \\
$13.20 f-h$
\end{tabular} & $\begin{array}{c}14.13 \mathrm{~b} \\
14.20 \mathrm{~b} \\
14.00 \mathrm{bc}\end{array}$ & $\begin{array}{l}83.67 b \\
83.17 b \\
84.78 a\end{array}$ & $\begin{array}{c}84.00 a \\
82.89 a b \\
86.22 a\end{array}$ & $\begin{array}{l}73.55 a \\
73.33 a \\
74.02 a\end{array}$ & $\begin{array}{c}74.00 a \\
71.78 a b \\
75.11 a\end{array}$ & $\begin{array}{l}63.22 a \\
63.00 a \\
64.78 a\end{array}$ & $\begin{array}{l}68.44 a \\
66.44 a \\
68.44 a\end{array}$ \\
\hline & $\begin{array}{l}\frac{0}{u} \\
\vdots \\
\vdots\end{array}$ & $\left|\begin{array}{ll}S & 106 \\
S & 107 \\
S & 108\end{array}\right|$ & \begin{tabular}{||c}
$12.86 \mathrm{i}-\mathrm{I}$ \\
$12.90 \mathrm{i}-\mathrm{k}$ \\
$12.63 \mathrm{k}-\mathrm{n}$
\end{tabular} & $\begin{array}{c}14.10 \mathrm{~b} \\
14.16 \mathrm{~b} \\
14.03 \mathrm{bc}\end{array}$ & $\begin{array}{c}80.22 \mathrm{i} \\
78.55 \mathrm{k} \\
81.44 \mathrm{f}-\mathrm{h}\end{array}$ & $\begin{array}{c}78.44 b c \\
77.33 c \\
79.55 b c\end{array}$ & $\begin{array}{c}73.11 a \\
72.44 a b \\
73.22 a\end{array}$ & $\begin{array}{l}68.44 c \\
68.00 c \\
68.44 c\end{array}$ & $\begin{array}{c}63.00 a b \\
63.33 a \\
63.66 a\end{array}$ & $\begin{array}{c}60.67 a \\
59.55 a b \\
60.67 a\end{array}$ \\
\hline \multirow{3}{*}{ 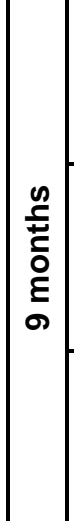 } & $\begin{array}{l}\frac{0}{4} \\
\Delta \\
\Lambda\end{array}$ & $\left|\begin{array}{ll}S & 106 \\
S & 107 \\
\text { S } & 108\end{array}\right|$ & \begin{tabular}{|c}
$15.26 a-c$ \\
$15.40 a$ \\
$15.13 b-c$
\end{tabular} & $\begin{array}{c}14.33 a b \\
14.43 a \\
14.33 a b\end{array}$ & $\begin{array}{l}80.97 \mathrm{~h} \\
80.22 \mathrm{i} \\
82.93 \mathrm{c}\end{array}$ & $\begin{array}{c}80.67 b \\
78.44 b c \\
81.78 a b\end{array}$ & $\begin{array}{l}72.55 a b \\
72.22 a b \\
72.77 a b\end{array}$ & $\begin{array}{l}68.44 c \\
68.44 c \\
70.67 b\end{array}$ & $\begin{array}{l}61.44 b c \\
61.33 b c \\
61.55 b c\end{array}$ & $\begin{array}{l}57.11 \mathrm{ab} \\
46.88 \mathrm{bc} \\
57.55 \mathrm{ab}\end{array}$ \\
\hline & 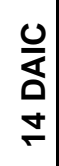 & $\left|\begin{array}{ll}S & 106 \\
S & 107 \\
S & 108\end{array}\right|$ & \begin{tabular}{|c}
$13.23 e-h$ \\
$13.36 e f$ \\
$13.16 f-h$
\end{tabular} & $\begin{array}{c}14.13 b \\
14.20 b \\
14.00 b c\end{array}$ & $\begin{array}{c}82.89 \mathrm{~cd} \\
82.00 \mathrm{ef} \\
83.67 \mathrm{~b}\end{array}$ & $\begin{array}{c}82.89 a b \\
80.67 b \\
86.22 a\end{array}$ & $\begin{array}{c}72.44 \\
72.00 \mathrm{ab} \\
72.66 \mathrm{ab}\end{array}$ & $\begin{array}{c}71.78 a b \\
67.33 c \\
74.00 a\end{array}$ & $\begin{array}{c}61.66 b c \\
61.55 b c \\
62.22 b\end{array}$ & $\begin{array}{c}60.66 a \\
56.22 a b \\
62.77 a\end{array}$ \\
\hline & $\begin{array}{l}\frac{0}{u} \\
\vdots \\
\vdots\end{array}$ & $\left|\begin{array}{ll}S & 106 \\
S & 107 \\
S & 108\end{array}\right|$ & \begin{tabular}{|c}
$12.63 k-n$ \\
$12.76 j-m$ \\
$12.43 n o$
\end{tabular} & $\begin{array}{c}14.16 \mathrm{~b} \\
14.30 \mathrm{ab} \\
13.83 \mathrm{c}\end{array}$ & $\begin{array}{l}78.33 \mathrm{k} \\
77.33 \mathrm{I} \\
79.82 \mathrm{j}\end{array}$ & $\begin{array}{c}78.44 b c \\
77.33 c \\
78.44 b c\end{array}$ & $\begin{array}{c}72.22 a b \\
70.66 c \\
72.44 a b\end{array}$ & $\begin{array}{c}68.44 c \\
67.33 c \\
69.55 b c\end{array}$ & $\begin{array}{c}62.00 \mathrm{~b} \\
61.33 \mathrm{bc} \\
62.22 \mathrm{~b}\end{array}$ & $\begin{array}{c}49.55 b c \\
47.11 c \\
52.89 b\end{array}$ \\
\hline \multirow{3}{*}{ 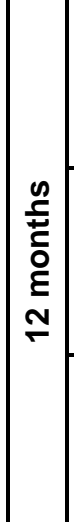 } & $\begin{array}{l}0 \\
\frac{0}{\Delta} \\
\Lambda\end{array}$ & $\left|\begin{array}{ll}S & 106 \\
S & 107 \\
\text { S } & 108\end{array}\right|$ & \begin{tabular}{|c}
$15.03 \mathrm{~cd}$ \\
$15.26 \mathrm{a}-\mathrm{d}$ \\
$15.00 \mathrm{~d}$
\end{tabular} & $\begin{array}{r}14.43 a \\
14.62 a \\
14.03 b c\end{array}$ & $\begin{array}{c}80.23 \mathrm{i} \\
79.22 \mathrm{j} \\
81.89 \mathrm{e}-\mathrm{g}\end{array}$ & $\begin{array}{c}80.66 b \\
80.66 b \\
79.55 b c\end{array}$ & $\begin{array}{l}71.33 b \\
70.88 c \\
71.33 b\end{array}$ & $\begin{array}{c}69.55 b c \\
67.33 c \\
70.66 b\end{array}$ & $\begin{array}{l}60.00 c \\
59.78 d \\
60.66 c\end{array}$ & $\begin{array}{c}50.89 \mathrm{~b} \\
48.44 \mathrm{bc} \\
54.44 \mathrm{~b}\end{array}$ \\
\hline & $\begin{array}{l}0 \\
\\
0 \\
\dot{T}\end{array}$ & $\left|\begin{array}{ll}S & 106 \\
\text { S } & 107 \\
\text { S } & 108\end{array}\right|$ & $\mid \begin{array}{c}12.86 \mathrm{i}-\mathrm{I} \\
13.06 \mathrm{~g}-\mathrm{i} \\
12.96 \mathrm{~h}-\mathrm{j}\end{array}$ & $\begin{array}{l}13.93 c \\
14.43 a \\
13.93 c\end{array}$ & $\begin{array}{l}\text { 82.26de } \\
81.55 f-h \\
82.67 \mathrm{~cd}\end{array}$ & $\begin{array}{c}81.78 a b \\
80.66 b \\
84.00 a\end{array}$ & $\begin{array}{l}71.11 b \\
70.12 c \\
71.58 b\end{array}$ & $\begin{array}{c}70.67 b \\
68.44 c \\
71.78 a b\end{array}$ & $\begin{array}{l}60.88 \mathrm{c} \\
60.00 \mathrm{c} \\
61.22 \mathrm{bc}\end{array}$ & $\begin{array}{c}59.55 a b \\
58.44 a b \\
60.6 a 6\end{array}$ \\
\hline & 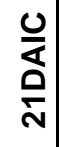 & $\left|\begin{array}{ll}S & 106 \\
S & 107 \\
S & 108\end{array}\right|$ & $\begin{array}{c}12.36 \mathrm{no} \\
12.53 \mathrm{mn} \\
12.16 \mathrm{o}\end{array}$ & $\begin{array}{c}14.03 b c \\
14.16 b \\
13.70 c\end{array}$ & $\begin{array}{c}77.44 \mathrm{l} \\
76.44 \mathrm{~m} \\
78.44 \mathrm{k}\end{array}$ & $\begin{array}{c}79.55 b c \\
75.11 c \\
79.55 b c\end{array}$ & $\begin{array}{l}70.44 c \\
70.00 c \\
70.88 c\end{array}$ & $\begin{array}{l}68.44 c \\
67.33 c \\
69.55 b c\end{array}$ & $\begin{array}{c}59.55 \mathrm{~d} \\
59.50 \mathrm{~d} \\
61.47 \mathrm{bc}\end{array}$ & $\begin{array}{l}47.33 c \\
44.44 c \\
50.66 b\end{array}$ \\
\hline
\end{tabular}

DAIC= Days after irrigation cut off, $S=$ Sakha. Means of each column designated by the same latter are not significantly different at $5 \%$ level using Duncan's Multiple Range Test 
Samah M. Aamer, et al.,

Table 6: Amylose, elongation percentages and gelatinization temperature (GT) as affected by the interactions among harvest time, storage times and rice cultivars in combined analysis for the three storage periods during 2018 and 2019 seasons.

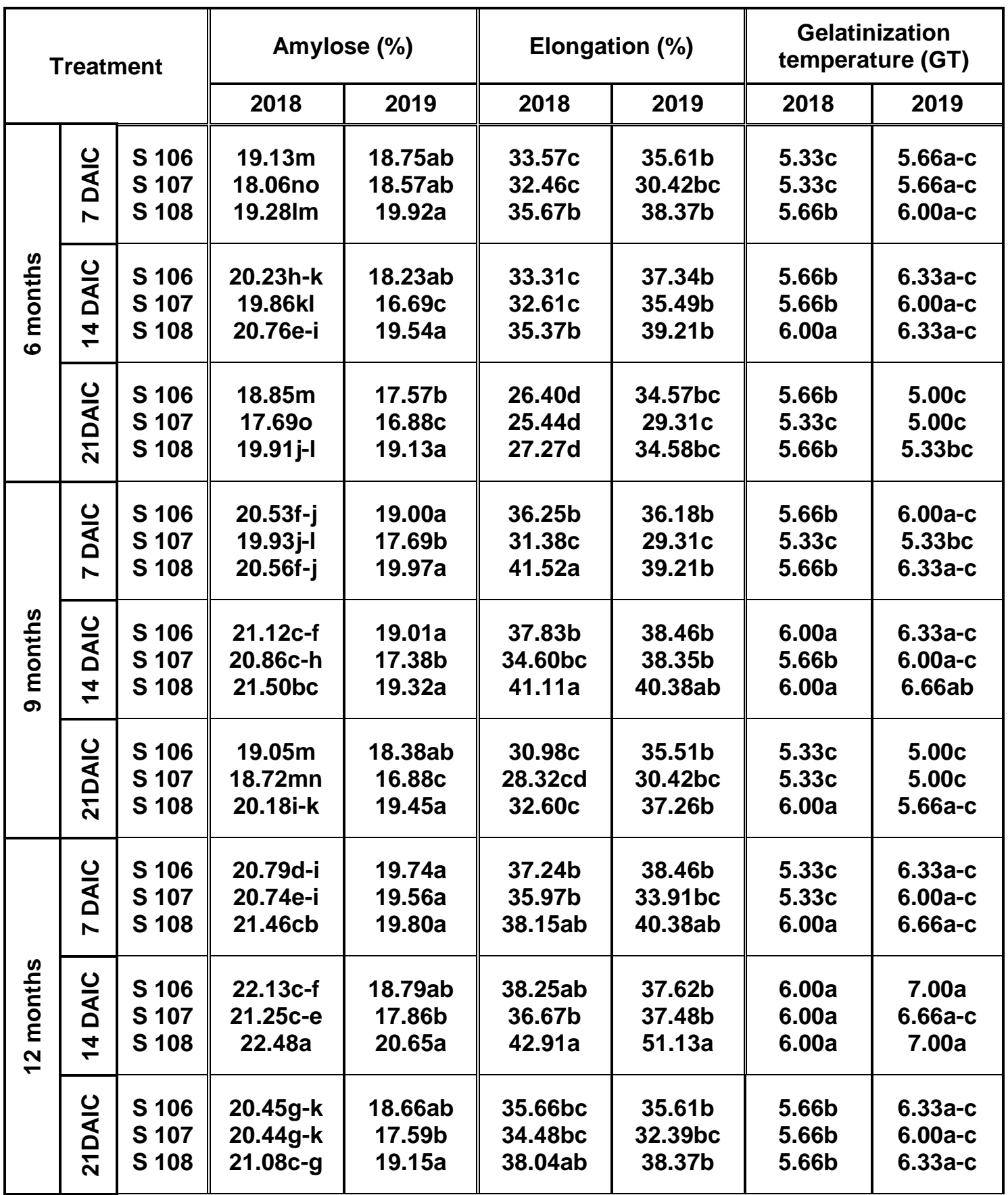

DAIC= Days after irrigation cut off, $S=$ Sakha. Means of each column designated by the same latter are not significantly different at $5 \%$ level using Duncan's Multiple Range Test

\section{CONCLUSION}

It can be concluded that harvesting after 14 DAIC with Sakha 108 rice cultivar achieved the highest grain yield and quality characteristics at the 9-month storage period. 


\section{REFERENCES}

Afifah, A., M. S. Jahan, M. Khairi and M. Nozulaidi (2015). Effect of various water regimes on rice production in lowland irrigation. Australian Journal of Crop Science, 9(2): 153-159.

Atapattu, A.J., B.R. Prasantha, K. S. P. Amaratunga and B. Marambe (2018). Increased rate of potassium fertilizer at the time of heading enhances the quality of direct seeded rice. Chemical and Biological Technologies in Agriculture, 5(1):1-9.

Baktiar, M. H. K., M. A. Siddique, M. Khalequzzaman, A. Bhuiya and M. Z. Islam (2013). Effect of maturity period and harvesting time on quality and yield in breeder seed of rice (Oryza sativa L.). Eco-friendly Agricultural Journal, 6(11):249-252.

Dewedar, G. A. A. (2004). Effects of some a agricultural practices on yield, yield components and some technological characters. M.Sc. Thesis, Fac. of Agric., Al-Azahr Univ., Egypt.

Duncan, D. B. (1955). Multiple range and multiple F. test. Biometrics, 11: 1-24.

El-Dalil, M. (2017). Effect of parboiling and storage periods on grain quality characters of G179 rice cultivar. Alexandria Science Exchange Journal, 38(July-September):537-542.

El-Kady, A.A., S.H. Abou Khadra, N.N. Bassuony and H.M. Hassan (2013). Effect of storage conditions on grain quality characters of some special rice varieties. Egyptian Journal of Plant Breeding, 203(1131):1-15.

Gomez, K.A. and A.A. Gomez (1984). Statistical procedures for agricultural research. John Wiley and Sons.

Howida, B. El-Habet, A. El-Megeed and M. Osman (2018). Performance of some rice genotypes under both different nitrogen levels and plant spaces. Journal of Plant Production, 9(10):.845-858.
Hossain, M.F., M.S.U. Bhuiya, M. Ahmed and M.H. Mian (2009). Effect of harvesting time on the milling and physicochemical properties of aromatic rice. Thai J. Agric. Sci., 42(2): 91-96.

llieva, V., N. Markova Ruzdik, D. Valcheva, L. Mihajlov and M. Ilievski (2019). Effect of harvest time of paddy on milled rice yield and broken kernels. Agricultural Science and Technology, 11(4): 327-331.

IRRI (International Rice Research Institute). (1996). Standard evaluation System for Rice. International Rice Research Institute (IRRI), P.O. Box 933, 1099 Manila, Philippines.

Jewel, M.H., M.R. Rahman, M.M. Rahman and M.J. Islam (2016). Effect of variety and date of harvesting on yield performance of boro rice. Fundamental and Applied Agriculture, 1(2): 66-69.

Juliano, B.O. (1971). A simplified assay for milled rice amylose. Cereal Sci. Today (16): 334-338.

Jungtheerapanich, S., K. Tananuwong and J. Anuntagool (2017). Aging kinetics of low amylose rice during storage at ambient and chilled temperatures. International Journal of Food Properties, 20(8):1904-1912.

Kanlayakrit, W. and M. Maweang (2013). Postharvest of paddy and milled rice affected physicochemical properties using different storage conditions. International Food Research Journal, 20(3):1359-1366.

Katta, M.Y., M.M. Kamara, S.M. Abd ELAty, H.W. Elgamal, M.R. Solelman, M.K. Mousa and T. Ueno (2019). Effect of storage temperature on storage efficacy, germination and physical characters of some paddy rice cultivars during different storage periods. Journal of the Faculty of 
Samah M. Aamer, et al.,

Agriculture, Kyushu University, 64(1):61-69.

Little, R.R., G.B. Hilder and E.H. Dowson (1858). Differential effect of dilute alkali on 25 varieties of milled white rice. Cereal Chem. 35: 111-126.

Marques, E.R., E.F. Araújo, R.F. Araújo, Martins Filho, S. and P.C. Soares (2014). Seed quality of rice cultivars stored in different environments. Journal of Seed Science, 36(1):32-39.

Metwally, T.F., H.M. El-Zun and N.A. Abdelfattah (2016). Performance of some rice genotypes sown on different dates in yield, quality traits and infestation by lesser grain borer. Journal of Plant Production, 7(9):973981.

Rather, T.A., M.A. Malik and A.H. Dar (2016). Physical, milling, cooking, and pasting characteristics of different rice varieties grown in the valley of Kashmir India. Cogent Food \& Agriculture, 2(1) Article: 1178694.
Tong, C., H. Gao, S. Luo, L. Liu and J. Bao (2019). Impact of postharvest operations on rice grain quality: A review. Comprehensive reviews in food science and food safety, 18(3), pp.626-640.Tsado, E. K. ; A. S. Gana ; S. T. Yusuf ; E. Daniya and A. Musa (2015). Effect of storage period of paddy rice on grain fissures and breakages of milled rice. J. of Environ. Sci., Toxic. and Food Tech., 9(2): 8-17.

Verma, D.K., M. Mohan, P.K. Prabhakar and P.P. Srivastav (2015). Physicochemical and cooking characteristics of Azad basmati. International Food Research Journal, 22(4): 1380.

Yang, X., B. Wang, L. Chen, P. Li and C. Cao (2019). The different influences of drought stress at the flowering stage on rice physiological traits, grain yield, and quality. Scientific reports, 9(1): 1-12.

Zhu, F., Y.Z. Cai, J. Bao and H. Corke (2010). Effect of Y-irradiation on phenolic compounds in rice grain. Food Chemistry, 120(1): 74-77. 
تأثير مواعيد الحصاد على محصول الحبوب و صفات جودة الحبوب لبعض أصناف الأرز عند فترات تخزين مختلفة

سماح محمد عامر، عبدالفتاح صبحي غريب وحسناء عبد الحميذ غازي قسم بحوث الأرز - معهد بحوث المحاصيل الحقلية - مركز البحوث الزراعية - سخا - كفر الثيخ - مصر عرئ الملخص العربي أجريت تجريتان حقليتان في المزرعة البحثية بمحطة البحوث الزراعية بسخا - كفر الثيخ - مصر ، خلال موسمي

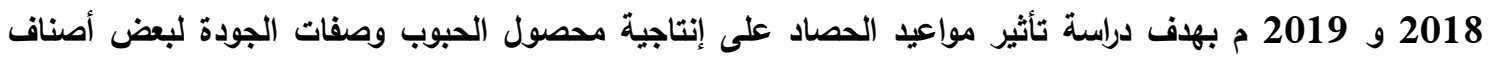
الأرز عند التخزين لفترات مختلفة. استخدم تصميم القطع المنثقة مرة واحده في ثلاثة مكررات، حيث احتوت دوادئ القطع

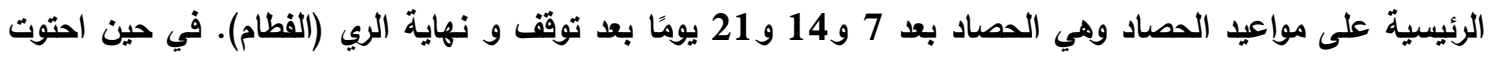

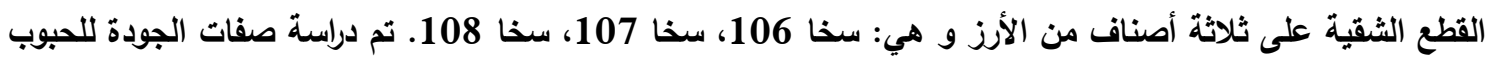

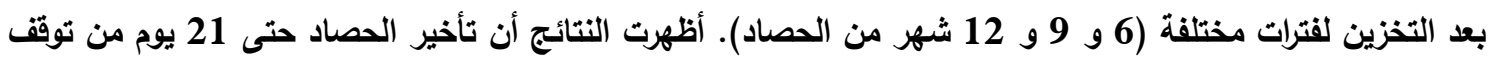

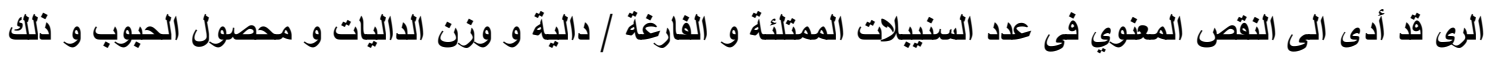
بالمقارنة بمواعيد الحصاد بعد 7 و 14 يوم من توقف الري. فى حين زادت وزن الـ الـ 1000 سنيبلة معنويا مع تأخير

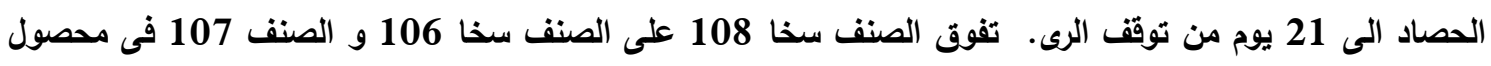

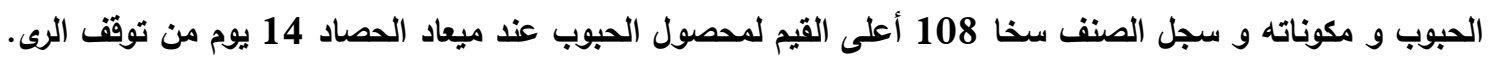
أدت زيادة فترات التخزين من 6 الى 9 و 12 شهر الى النقص التدريجى فى صفات التبيض (محتوى الرطوية و نسبة

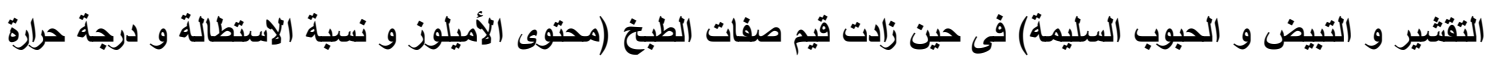

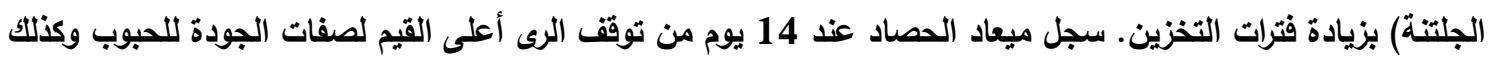
سجل الصنف سخا 108 أقل محتوى للطوية فى الحبوب و أعلى القيم لباقى صفات الجودة المدروسة.

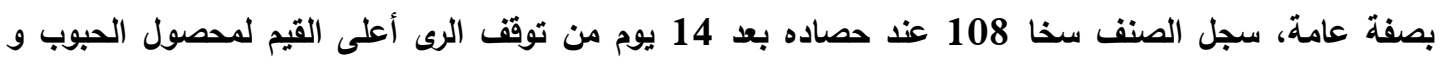
صفات الجودة وذلك بعد التخزين لمدة 9 أشهر.

أسماء السادة المحكمين

كلية الزراعة - جامعة كفر الثيخ أ.د / سعد حسن أبو خضره

أ.د/ إسماعيل سعد الرفاعى مركز البحوث الزراعية الزية 